\title{
ENGAGING THE STUDENTS WITH STYLES IN EFL PERSPECTIVES
}

\author{
Atik Sri Rahayu \\ Universitas Negeri Malang \\ atik.rahayu@gmail.com
}

\begin{abstract}
The active participation of students in the classroom is considered as the essential component in the learning. It is closely related to the students' engagement, which involves the students' interest, positive attitude and enjoyment towards learning. One crucial factor which influences the students' engagement in the classrooms is the teachers' teaching styles. The teachers' behaviors, beliefs and personality in teaching really influence their styles in teaching. Therefore, teaching styles become crucial since it can build and shape the students' learning experience in the classrooms.
\end{abstract}

\section{Key words: Students’ Engagement, Teaching Style, Participation}

\section{INTRODUCTION}

The students participation in the teaching and learning activities is regarded as the essential component to support the learning outcomes, especially in the English as Foreign Language classrooms. The active participation of students really influenced the direction of teaching and learning activities, which in turn will influence the success of the teaching and learning process. The term of active participation is closely related to the students' engagement during the teaching and learning activities because the students who are engaged will be involved and interested in the course materials and learning because the students are the central focus in the learning process.

The students' engagement can be defined as the student's psychological investment and efforts in the learning process to understand and master the materials, skills and instructions given (Newman, 1992). Therefore, engagement represents the students' psychological and cognitive efforts in accomplishing the tasks, not only the amount of energy they need to complete the tasks assigned. The students are cognitively and intentionally involved in any learning activities. Stern (1992) stated that, the effective learning is mostly depending on the learners' conscious and intentional engagement in learning activities to achieve particular goals. Therefore, the classroom engagement is different from the concept of 
motivation. It mostly deals with the students' attitudes toward learning, students' interest, time on task and enjoyment in the learning.

The significance of the students' engagement has become the attention of scholars recently. Mackenzie (2015) claimed that the desirable learning outcomes can be best accomplished through an active process which involves the engagement of the students during the learning process. Furthermore, research showed that the students learn best and retain more by actively doing, such as when they are engaged in the learning process rather than through passive learning (Carini, R; Kuh, D \& Klein, S., 2006; Petress, 2006). The students' engagement involves the students' attention, interest, investment and efforts in the learning (Marks, 2000) which considered as the students' intentional involvement in the learning activities in the classroom. Therefore, the classroom engagement is different from the school engagement in general. The students' engagement at the school level commonly involves the engagement of students as viewed from their participation in the extracurricular activities, attendance and the records of referrals and suspensions (Wang, Bergin \& Bergin, 2014). Thus, the engagement in school level has the different aspects with the engagement in the classroom, which emphasize on the students intentional involvement in the learning activities directly.

Fredricks, Blumenfeld \& Paris (2004) classified engagement into three dimensions. They are affective (emotional), cognitive and behavioral. Affective engagement refers to the positive emotions during the learning activities. It may be in the form of interest, enjoyment and enthusiasm in the learning. The cognitive engagement relates to the mental efforts such as the strategy used, concentration and metacognition. The behavioral engagement refers to the observable behavior that the students possess during the learning. It can be in the form of time-on tasks, active participation in the discussion, questions asking, and any other positive behavior in the classroom.

Engaging the students in the learning process was also considered as the biggest challenge for the teachers (Cothran \& Ennis, 2000; Willms, 2003). Therefore, if the teachers expect the students to be engaged and participate in the learning process actively, the teachers need to modify their approach to enhance the students' engagement in the classroom activities so that the students interact deeply with materials given and the meaningful learning can be reached (Grasha, 1990; Huba \& Freed, 2000). The active students are more likely to 
participate in the teaching and learning process, which may lead to the desirable learning success.

However, the students' ability and readiness to learn does not only depending on the students themselves, but also in the suitability of a teachers' teaching style (Felder \& Henrique, 1995). This is because the English teaching and learning process involves two main active variables in the classroom, teachers and students. Teachers play important roles in the instructional activities to achieve the learning objectives. Brown (2007:251) points out that the teachers must play many important roles at the same time. The roles can be the authority figure, leader, knower, director, manager, counselor, guide and even other roles as friend, confidant and parent. He furthermore claims that some of those roles will be more prominent than other roles from the students' point of view. The teachers' roles become essential since it will influence the whole process of teaching and learning to be more effective, which in turn will determine the success of the teaching and learning process.

The effective teaching and learning process will occur if there is mutual understanding between the teachers and the students about what should be done and why by both parties (Williams \& Burden, 1997), therefore the teachers take the important roles as mediator in selecting and shaping learning experience to the students (Feuerstein, cited in Williams \& Burden, 1997). The mutual understanding can be obtained from the students' expectation of the teachers through their style in teaching (Kassaian \& Ayatollah, 2010). This is because the teachers' styles in teaching can influence how they deliver the materials, interact with the students and manage the learning activities.

The ways the teachers teach are really influenced by their personality traits, behaviors and characteristics (Grasha, 1996). Peacock (2001) defined teaching style as the natural and habitual ways of a teacher in presenting new the information and skills in the classroom. In addition, Conti (1989) stated that teaching styles related to the persistent qualities and characteristics of the teachers in the classroom and considered consistent in various situations. This means that the teachers' teaching styles will remain constant even when the teachers use several teaching methods and techniques. In line with this, Brown (2007:251) asserts that "teaching styles will almost always be consistent with teacher's personality style, which can vary greatly from individual to individual". Therefore, teachers have different ways in managing their classes, interacting with their students and viewing their own roles as educators. However, Cook (2008) argued that the teaching styles represented the dynamic 
elements and changeable in teaching. Thus, teachers may modify and adjust their styles in teaching based on the class experiences.

On the other hand, students are simply unique as well as the teachers as viewed from the personality perspectives. As the humanistic approach introduced in the education, it comes with the notion that "humanistic education starts with the idea that students are different, and it strives to help students become more like themselves and less like each other". (Hamachek in Williams \& Burden, 1997:36). Therefore, every student learns and responds to any kinds of information received in unique manner. Teachers can serve better to fulfill the students' learning needs through the appropriate teaching styles.

\section{THE STUDENTS' ENGAGEMENT}

The students' engagement is closely related to the active participation of students in the learning activities. Therefore, the students' engagement is increasingly valued as the indicator of successful teaching and learning activities since the engaged students will participate actively and interested in the materials given. The students' engagement can be defined as the student's psychological investment and efforts in the learning process to understand and master the materials, skills and instructions given (Newman, 1992). The engagement represents the students' psychological and cognitive efforts in accomplishing the tasks, not only the amount of energy they need to complete the tasks assigned. The students are cognitively and intentionally involved in any learning activities.

Kuh et al. (2007) defined the students' engagement as participation in educationally effective practices. The red line of these definitions is the students' willingness, need, desire and compulsion to participate and be successful in the learning process. Therefore, the engagement is different from motivation. It deals with the students' attitude towards learning, students' interest, time on task and enjoyment in the learning. The students' engagement is more than involvement and participation. It requires feelings and sense making as well as activity (Harper \& Quaye, 2009). Fredricks, Blumenfeld and Paris (2004) identified three dimensions of students' engagement as follows:

a. Affective Engagement

The affective engagement deals with the positive emotions during the learning activities. It may be in the form of interest, enjoyment and enthusiasm in the learning. 
The students who are emotionally engaged would show the affective reasons in learning such as interest, enjoyment and sense of belonging.

\section{b. Cognitive Engagement}

The cognitive engagement related to the mental efforts in the learning activities. It involves the strategy used, concentration and metacognition. The students who are cognitively engaged would be invested in learning. They would seek to go beyond the requirements and enjoy the challenge.

c. Behavioral Engagement

The behavioral engagement can be measured from the observable behavior that the students posses during the learning. It can be in the form of time-on tasks, active participation in the discussion, asking questions, and any other positive behavior in the classroom. This engagement leads the students to comply with the prevailing behavioral norms like attendance and involvement. The students tend to demonstrate positive behavior towards learning.

\section{THE TEACHING STYLE}

Teachers do not come to the classroom they teach by leaving all their life experiences, beliefs and expectation behind. Rather, they are influenced and even shaped by those elements. (Conti, 1990:80) clearly stated that "as a teacher, you do not randomly select your teaching style, and you do not constantly change your style, which in turn is a subset of your overall philosophy". Therefore, it can be said that there are as many teaching styles as there are teachers. However, there are always the common patterns showing the characteristics of styles in teaching. In general, teaching style refers to classroom behavior as carried out by the teacher. It is not restricted to a teaching method or technique. Sometimes, the term "teaching style" may have the ambiguous interpretations with the teaching strategy. Simply, teaching strategy related to the specific activities, which are used to enhance the method of instruction. While teaching style is associated with the teacher's personal teaching and learning experience, educational background or even the cultural background. Genc \& Ogan-Bekiroglu (2004) defined teaching styles as the teachers' behaviors and attitudes during the teaching process in the classroom. Conti (1989) described teaching style as the overall traits and qualities that a teacher displays in the classrooms and that are consistent for various situations. The term 'consistent' means that the teaching style is persistent in various situation 
and learning conditions. In other words, teachers' teaching styles will remain the same even when they use different teaching techniques and strategies. However, Cook (2008) argues that word 'style' reflects the element of dynamic and thus, it is changeable in teaching a language. Accordingly, even though the teaching style is considered persistent, it does not mean that the teacher cannot modify or change their styles in teaching. They still can modify their teaching styles to adjust with the learning circumstances. The adjustment and modification of teaching style can provide a more successful learning and teaching experiences.

The styles of teachers in teaching are influenced by the way they learn. Stitt-Goheds (2001) stated that most teachers teach based on the way they were taught. This means that teachers reflected their experience when they were students. How their teachers treated them during the teaching and learning process might inspire them in doing the similar ways. They tend to reflect what they got in their former experience to their students. Therefore, teachers need to adjust their preference styles in teaching to reach their students respectively.

Grasha (1996) viewed styles in teaching as several aspects or elements that teachers show in every teaching and learning process. These elements include behaviors, roles, instructional practices, characteristics and beliefs. The teachers should avoid teaching as they were taught or simply repeating how they taught the last time because time is changing, and students' development is changing as well.

\section{THE TEACHING STYLE CATEGORIES}

There are several different categories of teaching styles proposed by various researchers. Grasha (1996) proposed six models of teaching styles. They are expert, formal authority, personal model, facilitator, and delegator styles.

\section{a. Expert Style}

Teachers with this type of style possess knowledge and expertise that students need. They strive to maintain status as an expert among students by displaying detailed knowledge and by challenging students to enhance their competence. They concerned with transmitting information and ensuring that students are well prepared.

b. Formal Authority Style

Teachers with this type of teaching style possess status among students because of knowledge and role as a teacher/ educator. They concerned with providing positive 
and negative feedback, establishing learning goals, expectations, and rules of conduct for students. They also concerned with the correct, acceptable, and standard ways to do things and with providing students with the structure they need to learn.

c. Personal Model Style

Teachers with this type of teaching style believe in "teaching by personal example" and establish a prototype for how to think and behave. They oversee, guide, and direct by showing how to do things, and encourage students to observe and then to emulate the instructor's approach.

d. Facilitator Style

Teachers with this type of teaching style emphasize the personal nature of teacherstudent interactions, guide and direct students by asking questions, exploring options, suggesting alternatives, and encourage them to develop criteria to make informed choices. The overall goal is to develop students' capacity for independent action, initiative, and responsibility. They work with students on projects in a consultative fashion and try to provide as much support and encouragement as possible.

e. Delegator Style

Teachers with this type of teaching style concerned with developing students' capacity to function in an autonomous fashion. Students work independently on projects or as part of autonomous teams. The teacher is available at the request of students as a resource person.

However, Grasha (1996) suggested that categorizing the teachers' teaching style into one of the five categories is considered "premature". Instead, each individual style is like different color on an artist palette, they can be blended together. Therefore, he developed four clusters of teaching styles as follows:

1. Cluster 1: expert/ formal authority style (i.e. traditional teacher-centered classroom processes).

2. Cluster 2: personal model/ expert/ formal authority style (i.e. provides personal modeling, guiding and coaching)

3. Cluster 3: facilitator/ personal model/ expert style (i.e. emphasizes on collaborative and student-centered learning processes)

4. Cluster 4: delegator/ facilitator/ expert style (i.e. emphasizes on independent group and individual learning activities) 
Another category of teaching styles was proposed by Sun (2007) who classified it into four different categories. They are authoritarian, democratic, laissez faire, and indifferent styles. The details of each category are as follows:

- Authoritarian Style

Authoritarian teachers are accustomed to have authority in the classroom. They establish all rules and regulations in class and specify particular consequences in the event of rules violation.

- Democratic Style

Democratic teachers set the expectations for students' behavior and learning firmly. However, they tend to be flexible and responsive to various students' needs. They give freedom to students to make their own decision in the teaching and learning process.

- Laissez Faire Style

Teachers who exhibit this style in teaching are described as caring and nurturing because they provide emotional supports to the students. However, they emphasize on the independent learning and rarely set expectations for students.

- Indifferent Style

Indifferent teachers focus on their personal work. They rarely spend time with their students or give extra attention to students beyond the teaching and learning process. They offer little or no emotional support. In addition, they rarely establish rules in the classroom to control students' learning experiences.

In addition, Cook (2008) classified teaching styles into six main classifications. He emphasizes the style in teaching English as a second and foreign language. The teaching style category she proposed involve academic style, audio lingual style, communicative style, taskbased learning style, mainstream EFL style and other style. The academic style is described as the teaching style which focuses on grammatical explanation and translation. The audiolingual style emphasizes on teaching the spoken language through dialogues and drills. The communicative style focuses on teaching language for meaningful communication to let the students interact with people both inside and outside the classroom. The task-based learning (TBL) style focuses on teaching language through meaning-based tasks with definite outcomes. The mainstream EFL style combines both academic and audio-lingual styles, while other styles looks beyond the language itself means that there are divergent styles and learners are free to choose the best style to suit their needs. However, the categorization of teaching styles as proposed by Vivian Cook (2008) seemed to expand the language teaching 
methods or techniques, which are in the different area of the teaching styles as discussed in this paper. Since teachers' teaching styles are associated with the behavior or beliefs as they bring to the classroom. Therefore, they are not restricted to the teaching methods or techniques (Cooper, 2001; Heimlich \& Norland, 2002; Jarvis, 2004).

\section{PREVIOUS STUDIES ON TEACHING STYLES}

Many researchers (Giles et.al. 2006; Heimlich \& Norland, 2002; Razak, Ahmad \& Shad, 2007; Soliven, 2006) found that teaching styles have fundamental elements to provide the students with good learning experiences and improve the students' academic outcomes. Kassaian \& Ayatollah (2010) conducted a research to find out the position of teaching styles and the optimal guidance in English language major. The findings showed that the students' opinion with respect to their favorite teaching styles converge when the teaching styles are regarded as a part of guidance. The teachers' opinions with respect to the students' favorite teaching styles are situated and context dependable. This means that the teachers are more sensitive to the requirements of the courses they teach than their students are.

Wong (2015) conducted a research on the relationship between language learning styles and teaching style preferences of Hong Kong community college students and teachers in English for academic purposes (EAP) context. He found that both students' learning styles and teaching styles are flexible and have a reciprocal influence on each other. This means that the teachers' styles in teaching influence them in giving the information, communicating with the students and supervising the coursework, and the students' perceptions towards the teaching also influence the teachers' style in teaching as well.

Other research conducted by Farkas (2003) investigated the influence of teaching styles to the students' learning style. He found that the students' who receive teaching styles which matched their preferred learning styles showed more positive attitudes towards learning, more understand the people's feelings and increase their ability to transfer what they have learnt during the learning process to other students.

Shaari, et al. (2014) also conducted a study to find a relationship between lecturers' teaching styles and students' academic engagement in a Malaysian university. The study found that there was significant relationship between the lecturers' teaching style with the students' academic engagement. 
However, the limited education research investigating the teaching styles in second/ foreign language education made this area to be regarded as an under research topic. Peacock (2001) considered the teaching styles as an important and under-research aspect in the second/ foreign language learning.

\section{STUDENTS' ENGAGEMENT AND TEACHING STYLES: ARE THEY RELATED?}

"Pedagogy should at its best be about what teachers do that not only help students to learn but actively strengthen their capacity to learn" (Hargreaves, 2004:27). This notion presents the importance of the teachers' roles in the teaching and learning process since what the teachers do will shape the learning experience of the students which in turn will influence the whole process of learning. The teachers' efforts to strengthen the students' capacity to learn become the essential factors since the students' capacity to learn can be well observed through their engagement during the learning activities.

The engagement of students becomes the crucial factors in learning since it closely related to the active participation of students in the learning activities. Therefore, the students' engagement is increasingly valued as the indicator of successful teaching and learning activities since the engaged students will participate actively and interested in the materials given. Newman (1992) stated that students' engagement involved the student's psychological investment and efforts in the learning process to understand and master the materials, skills and instructions given. In other words, the engagement represents the students' psychological and cognitive efforts in accomplishing the tasks, not only the amount of energy they need to complete the tasks assigned. The students are cognitively and intentionally involved in any learning activities.

English teaching and learning process involves two main variables in the classrooms, teachers and students. Therefore, the students' ability and readiness to learn does not only depending on the students themselves, but also in the suitability of a teachers' teaching style (Felder \& Henrique, 1995). Teachers play important roles in the instructional activities to achieve the learning objectives. The teachers' roles become essential since it will influence the whole process of teaching and learning to be more effective, which in turn will determine the success of the teaching and learning process. 
However, the effective teaching and learning process will occur if there is mutual understanding between the teachers and the students in the learning activities (Williams \& Burden, 1997). The teachers know what to do in the classroom to encourage the students to actively involve in the learning and the students also know the importance of doing so in the classrooms. Therefore, the teachers take the important roles as mediator in selecting and shaping learning experience to the students (Feuerstein, cited in Williams \& Burden, 1997). The mutual understanding can be obtained from the students' expectation of the teachers through their style in teaching (Kassaian \& Ayatollah, 2010). This is because the teachers' styles in teaching can influence how they deliver the materials, interact with the students and manage the learning activities.

One of the elements in engaging the students in the learning activities is through interaction (Windham, 2005). In this case, interaction means the respectful relationship between the students and teachers, which can be built in the classroom. Willms, Friesen \& Milton (2009) conducted a survey to figure out what the students want in the learning. The survey revealed that the students wanted their teachers to know how they learn. The students expected that the teachers will consider and give attention on the students' accomplishment in learning activities, whether they understand or misunderstand of the materials given. They hope that this will lead them to subsequent learning phase. This result showed that the students rely much on their teachers' roles in the classroom to guide them in learning activities. It is clearly seen that the teaching styles of teachers hold crucial roles in shaping the students' learning experience in the classroom since the teachers' teaching styles related to the teachers' behavior, beliefs and personality that they show in the classrooms. The survey also found that the students wanted the teachers to establish the good learning environment for them. The teaching styles of teachers play important roles in engaging the students in the learning activities since the teachers' teaching style will shape the learning experience of the students and thus will affect their engagement in learning. When the teachers are successful in creating the positive classroom climate, the students' engagement is on the right path. As stated by Willms, Friesten \& Milton (2009:35) that "students who describe their classroom disciplinary climate as positive are one and a half times more likely to report high levels of interest, motivation and enjoyment in learning".

\section{CONCLUSION}


It has been widely argued that the optimal learning occurs when there is mutual agreement or understanding between the teachers and the students about what should be done and why by both parties (Williams \& Burden, 1997) which can be referred to as reciprocity principle which often mismatched in the EFL classrooms. The sensitivity of teachers towards the students' expectations can be seen from their styles in teaching. Therefore, when the mutual understanding is not obtained, the teachers often complain about the students' lack of autonomy and independence in the learning activities while the students keep complaining about the teachers who do not give them enough guidance as expected. This situation may lead to the mismatch between the students and teachers' expectations pertaining to their teaching styles because teachers do not come to the classroom they teach by leaving all their life experiences, beliefs and expectation behind. Rather, they are influenced and even shaped by those elements

From the above discussion, it is undeniable that the students' engagement in the EFL classrooms is really influenced by the teachers' teaching styles. Teachers hold the prominent roles in the classroom to shape and build the climate of the learning environment from beginning to the end of learning activities. The students' engagement is regarded as the important component to encourage the skills and acquisition development through the students-centered learning.

In addition, the environment of learning also has significant influence to the learning activities (Shaari, et al., 2014). The environment which support the learning circumstances will give greater influence to the students' engagement in the learning process. Since there is still a lack of research in vocational school context in Indonesia, it is advised that the research in the area of teaching styles can be conducted in vocational setting in Indonesia. This is mostly because of the unique characteristics of vocational education along with the students in the learning activities. The differences of vocational and general high schools in Indonesia are obviously reflected from the students' registration, selection process up to the curriculum applied. For instance, it is very common in Indonesia that the students are sorted into school type based on their entering test scores. The general high schools attract most of the high achievers. As the results, the low achievers tend to choose the vocational high schools. In addition, the curriculum of vocational education is different from general education for it has special characteristics to establish the students' capacity suitable with the specific job performance. The capacity is accommodated in the vocational school curriculum comprising normative, adaptive and productive groups. Moreover, there is also the on-the-job training 
program, which has to be accomplished by all vocational students in their second year. The duration of the on-the-job training program ranges from 3 months up to 12 months depending on respective school policies. The students have to prepare well for this program since the results will determine the continuance of their study. This situation represents various colors in vocational education, which may lead to the disengagement of the students in the teaching and learning activities. These aspects showed the uniqueness of vocational high school, which in turn lead to special consideration required to its students to adjust with those special characteristics, especially in English teaching and learning.

\section{REFERENCES}

Brown, H. Douglas. 2007. Teaching by Principles: An Interactive Approach to Language Pedagogy (3rd Edition). Pearson Education Inc.

Carini, R.; Kuh, D.; Klein, S. 2006. Student Engagement and Student Learning: Testing the Linkages. Research in Higher Education, 47 (1), 1-32.

Conti, G.J. 1990. Identifying Your Teaching style in M. Gailbraith (Ed.) adult Learning Methods. Malabar, FL: Krueger.

Conti, G. J. 1989. Assessing Teaching Style in Continuing Education. In E. Hayes (Ed.), Effective Teaching Styles (pp. 3-16). San Francisco: Jossey-Bass.

Cook, Vivian. 2008. Second Language Learning and Language Teaching (Fourth Edition). London: Hodder Education:.

Cooper, C. 2001. Foreign Language Teaching Style and Personality. Foreign Language Annals, 34, 301-16.

Cothran, D. J., \& Ennis, C. D. 2000. Building Bridges to Student Engagement: Communicating Respect and Care for Students in Urban High Schools. Journal of Research and Development in Education, 33(4), 106-117.

Farkas, R. D. 2003. Effects of Traditional Versus Learning-Styles Instructional Methods on Middle School Students. The Journal of Educational Research, 97(1), 42-51.

Felder, R. M., \& Henriques, E. R. 1995. Learning and Teaching Styles in Foreign and Second Language Education. Foreign Language Annals, 28 (1), 21-31.

Fredricks, J.A., Blumenfeld, P.C. \& Paris, A.H. 2004. School Engagement: Potential of the Concept, State of the Evidence. Review of Educational Research. 74(1), pp. 59-109.

Genc, E., \& Ogan-Bekiroglu, F. 2004. Patterns in Teaching Styles of Science Teachers in Florida and Factors Influencing Their Preferences. Online Submission 2004.

Giles, J., Ryan, D. A. J., Belliveau, G., De Fritas, E., \& Casey, R. 2006. Teaching Style and Learning in a Quantitative Classroom. Active Learning in Higher Education, 7(3), 213225. 
Grasha, A. F. 1990. Using Traditional Versus Naturalistic Approaches in Assessing Learning Styles in College Teaching. Journal of Excellence in College Teaching, 1, 23-38

Grasha, Anthony. F. 1996. Teaching with Style. Pittsburgh, PA: Alliance Publishers.

Hargreaves, D. H. 2004. Learning for Life: the Foundations for Lifelong Learning. Bristol: Policy Press.

Harper, S.R. \& Quaye, S.J. 2009. Beyond Sameness, with engagement and Outcomes for all. In: Student Engagement in Higher Education, NY \& London: Routledge, pp. 1-15.

Heimlich, J. E., \& Norland, E. 2002. Teaching style: Where are we now? New Directions for Adult and Continuing Education, 93, 17-25.

Huba, M.E. \& Freed, J.E. 2000. Learner-Centered Assessment on College Campuses: Shifting the Focus from Teaching to Learning. Needham Heights, MA: Allyn \& Bacon

Jarvis, P. 2004. Adult Education and Lifelong Learning: Theory and Practice. London,England: Routledge.

Kassaian, Zohreh \& Ayatollah, Mohammad Ali. 2010. Teaching Styles and Optimal Guidance in English Language Major. Quarterly Journal of Research and Planning in Higher Education, No. 55, 2010, pp. 131-152.

Kuh, G.D., Kinzie, J., Buckley, J.A., Brdiges, B.K., \& Hayek, J.C. 2007. Piercing Together the Student Success Puzzles: Research, Proportions \& Recommendations. ASHE Higher Education Report, Vol. 32, No. 5. San Fransisco: Jossey-Bass.

Mackenzie, Allyson. 2015. Promoting Student Engagement in the English as a Foreign Language Classroom in a Japanese University. Journal of Business Administration, Vol. 86, pp. 129-143.

Newman, P.R. 1992. Conceptual Models of Student Engagement. National Center of Effective Secondary Schools. University of Wisconsin.

Peacock, M. 2001. Match or mismatch? Learning Styles and Teaching Styles in EFL. International Journal of Applied Linguistics, 11(1), 1-20.

Petress, K. 2006. An Operational Definition of Class Participation. College Student Journal, $40(4), 821-823$.

Razak, N.A., Ahmad, F., \& Shah, N.P. 2007. Perceived and preferred teaching styles (methods) of English for Specific Purposes (ESP) students. e-BANGI: Jurnal Sains Sosial dan Kemanusiaan, 2(2). Retrieved from http://journalarticle.ukm.my/1542/

Shaari, A.S., Yusoff, N.M., Ghazali, I.M., Osman, R.H. \& Dzahir, N.F.M. 2014. The Relationship between Lecturers' Teaching Style and Students' Academic Engagement. Social and Behavioral Science (118). 2014, pp. 10-20.

Soliven, S. R. 2003. Teaching styles of high school physics teachers. Retrieved from http://www.hiceducation.org/EduProceedings

Stern, H. H. 1992. Issues and Options in Language Teaching. Oxford: Oxford University Press.

Stitt-Gohdes, W. L. 2001. Business Education Students' Preferred Learning Styles and Their Teachers' Preferred Instructional Styles: Do They Match?. Delta Phi Epsilon Journal, 43(3), 137-151. 
Sun, M.-Y. \& Wang, C.-H. 2007. The Relationship between Teacher Discipline and Students Learning Motivation in School. Journal of Primary and Secondary Education Research Vol. 18, pp. 165-193.

Williams, Marion \& Burden, Robert L. 1997. Psychology for Language Teachers. Cambridge University Press.

Willms, J. D. 2003. Student Engagement at School: A Sense of Belonging and Participation. Results from PISA 2000. Paris: Organization for Economic Co-operation and Development (OECD).

Willms, J. D., Friesen, S. \& Milton, P. 2009. What did you do in school today? Transforming classrooms through social, academic and intellectual engagement. (First National Report) Toronto: Canadian Education Association.

Windham, C. 2005. The Student's Perspective. In D. Oblinger \& J. Oblinger (Eds), Educating the Net generation (pp. 5.1-5.16). Boulder, CO: EDUCAUSE.

Wang, Z., Bergin, D.A. \& Bergin, C.A. 2014. Measuring Engagement in Fourth to Twelft Grade Classrooms: The Classroom Engagement Inventory. School Psychology Quarterly

Wong, W.L.H. 2015. A Study of Language Learning Style and Teaching Style Preferences of Hong Kong Community College Students and Teachers in English for Academic Purposes (EAP) Context. Unpublished Doctorate Thesis. University of Canterburry. 